\title{
Recommendations for green development of motor biofuel industry in China: A review
}

\author{
Zongxi Zhang ${ }^{1}$, Gang $\mathrm{Li}^{2 *}$, Yinghua Zhang ${ }^{3}$, Jiang Zhang ${ }^{2}$, Chuanzeng Song ${ }^{1}$, Yuguang Zhou ${ }^{4,5,6}$ \\ (1. School of Mechanical and Electronic Engineering, Shandong Jianzhu University, Ji'nan 250101, China; \\ 2. School of Artificial Intelligence, Beijing Technology and Business University, Beijing 100048, China; \\ 3. Ji’nan Technician College, Jinan 250115, China; 4. Laboratory of Bioenergy and Environment Science \& Technology, \\ College of Engineering, China Agricultural University, Beijing 100083, China; \\ 5. Key Laboratory of Clean Production and Utilization of Renewable Energy, Ministry of Agriculture and Rural Affairs, Beijing 100083, China; \\ 6. National Center for International Research of BioEnergy Science and Technology, Ministry of Science and Technology, Beijing 100083, \\ China)
}

\begin{abstract}
Motor biofuel is one kind of clean and sustainable fuel extracted from living organisms or obtained by the transformation of organisms, which can be used to replace fossil fuels. Nowadays, motor biofuel is an important direction for the development and utilization of renewable energy. More attention has been given to the development and promotion of motor biofuel and relative technologies all over the world. This research introduced the history of motor biofuel, the classification of motor biofuel as well as the strategies and policies made domestically and internationally in order to promote the development of motor biofuel, and also pointed out some of the urgent problems faced during the development of motor biofuels and put forward some suggestions for the future development of motor biofuel in China.
\end{abstract}

Keywords: green development, motor biofuel, biodiesel, bioethanol, emission, renewable energy replacement DOI: $10.25165 /$ j.ijabe.20201305.3862

Citation: Zhang Z X, Li G, Zhang Y H, Zhang J, Song C Z, Zhou Y G. Recommendations for green development of motor biofuel industry in China: A review. Int J Agric \& Biol Eng, 2020; 13(5): 218-225.

\section{Introduction}

The automotive industry is the driving force to promote economic development and is also the benchmark of the national economy and scientific research strength. The automotive industry of China has developed rapidly in the past few decades. The automobile production and sales of China were 25.72 million and 25.77 million in 2019 , which decreased by $7.50 \%$ and $8.20 \%$ respectively when compared with 2018 (the date from Automobile Industry Association). Many social problems occurred due to the rapid development of the automobile industry, such as the shortage of energy, air pollution, noise pollution, traffic congestion, and public security. Fog and haze weather occurred frequently in large and medium cities since 2013 as a result of air pollution ${ }^{[1]}$.

Green, renewable alternative fuels for automobile have become more and more important as the shortage of fossil resources has increased, the crude oil price increased, and serious environmental pollution $^{[2]}$. The automobile using renewable energy sources as fuel is one of the most vital direction for the future development of

Received date: 2019-04-13 Accepted date: 2020-07-15

Biographies: Zongxi Zhang, PhD, Lecture, research interest: major in emission examining of biofuel combustion, Email: zongxizhang@outlook.com; Yinghua Zhang, Master, research interest: biomass engineering, Email: yszhangyinghua@163.com; Jiang Zhang, Master candidate, research interest: biomass engineering, Email: zjiang818@163.com; Chuanzeng Song, Master, Professor, research interest: emission reduction and control technology of engine, Email: 13012@sdjzu.edu.cn; Yuguang Zhou, PhD, Associate Professor, research interest: biomass utilization, Email: zhouyg@cau.edu.cn.

*Corresponding author: Gang Li, $\mathrm{PhD}$, Associate Professor, research interest: bioenergy engineering. School of Artificial Intelligence, Beijing Technology and Business University, Beijing 100048, China. Tel/Fax: +86-10-68985535, Email: ligang@btbu.edu.cn. automobile technology and also the best way to solve the above societal problem.

Fuel as the power source of the automobile is the most basic part of the entire automobile industry. Motor biofuel can replace gasoline and diesel as vehicle fuel, which is helpful for controlling the greenhouse effect, alleviating air pollution, and solving the energy crisis. The development cycle, cost, conversion rate, technology stability, and economic application of motor biofuel will affect the promotion of biofuel vehicles ${ }^{[3]}$.

The motor biofuel is in the early stages of industrial development as there are countless problems such as difficulty in collecting raw material, the immaturity of the technology, imperfect subsidy policy and immature market environment. This article comprehensively analyzed the development status and existing problem of motor biofuel and the measures taken globally to promote the development of motor biofuel, as well as putting forward some recommendations for the development of the motor biofuel and the industry in China.

\section{Motor biofuel}

\subsection{Conception of motor biofuel}

Motor biofuel was one type of sustainable and renewable fuel that can be extracted from organisms or obtained by transforming organisms, which can be used as an alternative fuel instead of fossil fuels ${ }^{[3]}$. Nowadays, bioethanol and biodiesel are the main motor biofuel used ${ }^{[4-6]}$.

\subsection{Histories of motor biofuel}

Motor biofuel production began in the late 19th century when bioethanol was extracted from corn. Motor biofuel was regarded as a viable fuel for automobiles until the 1940s. However, the reduction of petroleum and other fossil fuel price hampered the 
development of motor biofuel ${ }^{[3,7]}$. Renewable energy was actively developed globally due to the energy crisis and worldwide environmental pollution since the 1970s when the production of biofuel for transport increased. Motor biofuel caused widespread concern by the automotive consumers and agricultural countries as motor biofuels can be obtained by the utilization of agricultural and forestry waste. Motor biofuel is one of the most ideal alternative fuels for fossil fuel. Brazil, the United States of America (USA), and the European Union (EU) are at the forefront of the development of motor biofuel, providing abundant experience for the development of motor biofuel. The fastest growth of motor biofuel production occurred over the last 10 years, supported by the government and driven by energy security concerns ${ }^{[8]}$.

\subsection{Significance of motor biofuel}

Motor biofuel was the cornerstone energy for future vehicles as it can be used to replace fossil fuel. The combustion of ethanol and diesel $(20 \%$ ethanol and $80 \%$ diesel) reduced $62 \%$ of $\mathrm{CO}$ emissions and $24 \%$ of $\mathrm{NO}_{\mathrm{X}}$ emissions ${ }^{[9]}$. Particulate matter (PM) emissions can be reduced by $20 \%-40 \%$ with the combustion of diesel and ethanol blend ${ }^{[10,11]}$. The combustion of biodiesel and diesel reduced up to $20 \%-50 \%$ of $\mathrm{CO}$ emissions, $50 \%-60 \% \mathrm{HC}$ emissions, but increased $\mathrm{NO}_{\mathrm{X}}$ emissions by $13 \%{ }^{[12]}$. When using biodiesel in a heavy-duty diesel engine, PM emissions were decreased by $27 \%-43 \%$ and polycyclic aromatic hydrocarbons (PAHs) emissions were reduced by $47 \% \%^{[13]}$. Therefore, the utilization of motor biofuel could reduce greenhouse gas emissions, alleviate environmental pollution, and achieve great environmental benefits. The development of motor biofuel can reduce the country's dependence on fossil energy, protect national energy security, and fossil fuel could be used for the national strategic demand. The development of motor biofuel will improve the energy structure and reach the purpose of energy-savings and emissions reduction.

The utilization of ethanol-gasoline can replace four million tons of gasoline every year in China, which was an ideal way to solve the energy crisis and the air pollution problem. The promotion of ethanol gasoline in China has not only partially replaced petroleum, but also solved the problem of straw treatment ${ }^{[14,15]}$. Furthermore, as motor biofuel used agricultural, forestry, and industrial waste as raw materials, it is helpful in the management of urban waste and improving the health status of the town. Experts have evaluated that biofuel produced from the conversion of conventional agricultural waste resources would be able to supplement and eventually replace the need for combustion engine.

The safety and economic development of the motor biofuel industry has a significant influence on national energy consumption and the price of petroleum and other fossil fuel. It can also bring social benefits through the progress of the motor biofuel industry. Planting energy crops can promote the development and utilization of idle land, saline alkali soil, and improve the soil texture. Motor biofuel is being paid more attention as it can decrease the requirement for fossil fuel, alleviate environmental pollution, and promote the upgrading of the rural industry.

\section{Classification of motor biofuel}

\subsection{Motor biofuel classified by fuel type}

There are varieties of alternative fuels for automotive and considerable debate on how to classify them. Biodiesel, bioethanol, bio-based chemicals, and biogas were the four main kinds of motor biofuels ${ }^{[16-18]}$. The classification of alternative fuels for vehicles according to fuel type was given in Table $1^{[19-21]}$.
Table 1 Classification of motor biofuel, status and bottleneck during the development of motor biofuel

\begin{tabular}{ccc}
\hline Classification & Vehicle & Stage and bottleneck \\
\hline Traditional biodiesel & $\begin{array}{c}\text { Diesel } \\
\text { automobile }\end{array}$ & $\begin{array}{c}\text { BD20 has been achieved } \\
\text { commercialization; raw material collection } \\
\text { and production cost was high. }\end{array}$ \\
$\begin{array}{c}\text { Coal based two } \\
\text { methyl ether }\end{array}$ & $\begin{array}{c}\text { Modified diesel } \\
\text { automobile }\end{array}$ & $\begin{array}{c}\text { Demonstration application stage; storage } \\
\text { and transportation cost was high. }\end{array}$ \\
$\begin{array}{c}\text { Traditional crop } \\
\text { bioethanol }\end{array}$ & $\begin{array}{c}\text { Gasoline } \\
\text { automobile }\end{array}$ & $\begin{array}{c}\text { E10 has been achieved commercialization; } \\
\text { it was difficult for raw material collection, } \\
\text { storage and transportation; the production } \\
\text { petroleum gas and } \\
\text { liquefied natural gas) }\end{array}$ \\
$\begin{array}{c}\text { Gas vehicle, oil } \\
\text { and gas mixed } \\
\text { fuel vehicle }\end{array}$ & $\begin{array}{c}\text { Commercialized; Less fuel supply } \\
\text { network and storage difficulty. }\end{array}$ \\
Coal based methanol & $\begin{array}{c}\text { Modified } \\
\text { gasoline vehicle }\end{array}$ & $\begin{array}{c}\text { Some areas were in application } \\
\text { demonstration stage, such as Shanxi } \\
\text { province; toxicity and corrosion. }\end{array}$ \\
\hline
\end{tabular}

3.1.1 Biodiesel

Biodiesel was composed of fatty acid methyl esters (or fatty acid ethyl esters) and glycerin, which were the production of transesterification (called methyl esterification). The raw materials used for biodiesel production were vegetable oil, waste edible oil, and methanol. Biodiesel was a type of liquid biofuel that was produced by transesterification removed glycerin and unreacted oil ${ }^{[22,23]}$. The biodiesel industry developed quickly, and the output of biodiesel worldwide was shown linear growth during 2008-2018, as presented in Figure 1. Figure 2 showed the annual output and consumption of biodiesel from 2011-2017 in China, which indicated that biodiesel industry in China developed rapidly and biodiesel consumption was much more than that of output, meaning that there was still space and opportunity to develop the biodiesel industry in China.

The main raw materials for biodiesel production are soybean, peanut, rapeseed, yellow mustard and other herbal oil crops such as palm oil, olive oil, sunflower oil, and algae ${ }^{[24]}$. The cost of biodiesel production was dependent on the cost during the collection of raw material.

\subsubsection{Bioethanol}

Bioethanol can be made from energy crops through chemical treatment, distillation, and dehydration. Adding bioethanol into gasoline can be used as engine fuel ${ }^{[25]}$. The use of bioethanol was extremely important as it helps extend the supply of gasoline fuel. Bioethanol can be used to increase the oxygen content, as high-octane adjustable components, and also can be used to replace methyl tert butyl ether (MTBE) and ethyl tert butyl ether ${ }^{[26,27]}$. The annual output of bioethanol globally from 2008-2018 was shown in Figure 3. The output of bioethanol was shown to be slightly decreased during 2010-2011 and 2012-2013, however, it increased from 2014. The bioethanol production of China from 2008-2018 was shown in Figure 4, where it was observed that production increased rapidly in the past few years.

The raw material used for bioethanol production is grain crops such as corn (in the USA), sugarcane (Brazil), sugar beet, wheat and non-grain biomass (such as cassava, sweet potato, sweet sorghum, and plant straw $)^{[28]}$. The United States Department of Energy pointed out that bioethanol from cellulose was a focused research project in the future. Using cellulose for bioethanol production has been actively explored globally ${ }^{[29]}$. Bioethanol produced from cellulose faced some problems, such as cellulose was difficult to decompose. However, it is still the direction of the development of the world's biofuel industry to use cellulose for bioethanol production ${ }^{[30-32]}$. 


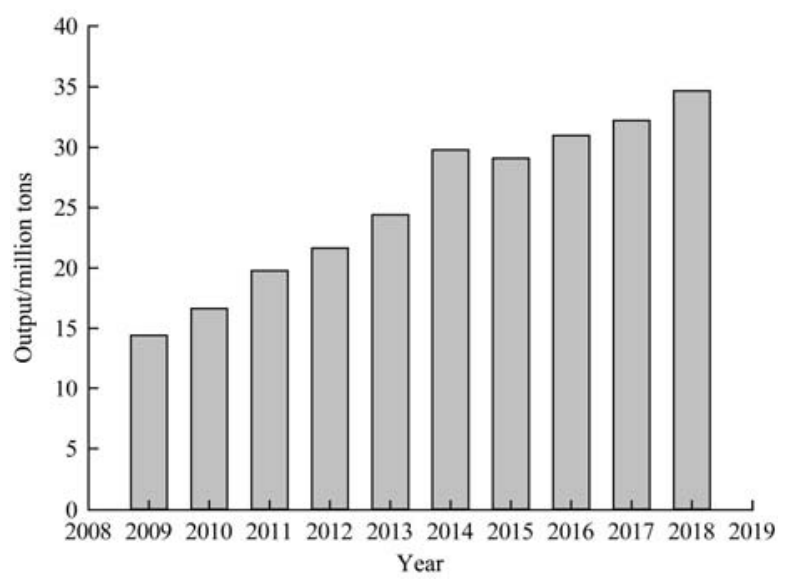

Source: Datacenter of the Earth Policy Institute.

Figure 1 Biodiesel output of the world from 2008 to 2018

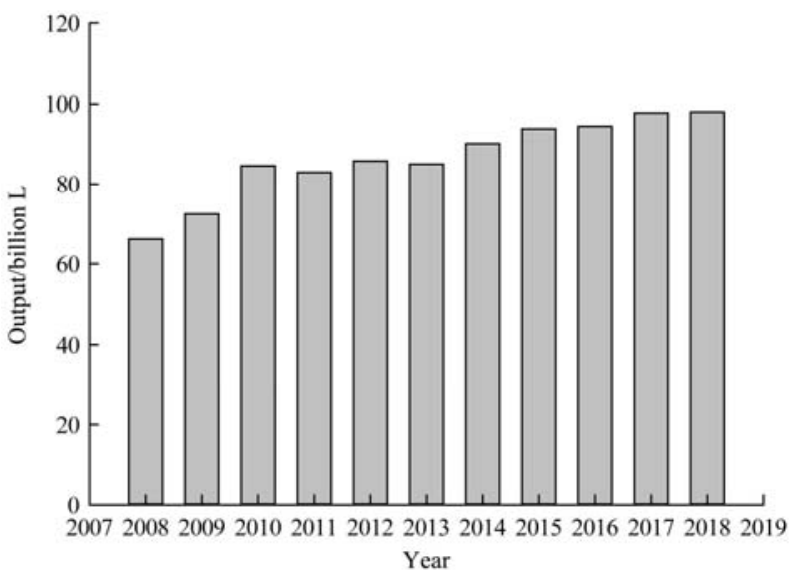

Source: Renewable fuels association analysis of public and private data sources

Figure 3 Annual output of bioethanol globally from 2008 to 2018

\subsubsection{Bio-based chemicals}

The raw materials used for ethyl tertiary butyl ether (ETBE) production were ethanol and isobutene. ETBE gasoline was produced by adding ethanol and isobutene into gasoline ${ }^{[33,34]}$. M-ETBE was obtained by adding ethanol and isobutene into gasoline. M-ETBE was a type of mixture where the main components were ETBE. Bio-oil can be made from the decomposition of wood and straw splitting without oxygen and then rapid condensation at the temperature of $500-600^{\circ} \mathrm{C}^{[35,36]}$. Adding a certain volume ratio or mass ratio of industrial bio-oil into diesel can use as engine fuel ${ }^{[37]}$.

\subsubsection{Biogas}

Biogas was the mixture of different gases, composed primarily of methane $\left(\mathrm{CH}_{4}\right)$, carbon dioxide $\left(\mathrm{CO}_{2}\right)$ and small amounts of hydrogen sulfide $\left(\mathrm{H}_{2} \mathrm{~S}\right)$, moisture and siloxanes, which can be produced through the anaerobic digestion include food waste, animal manure and sewage sludge, dedicated green energy crops such as maize, grass, and crop wheat ${ }^{[40]}$. Biogas was used for heating, cooking, and generating electricity. Biogas can be upgraded to biomethane by removing $\mathrm{CO}_{2}$ and $\mathrm{H}_{2} \mathrm{~S}$. Biomethane can also be used as fuel for the natural gas engine.

With the exception of the above biofuels, there were a number of liquid biofuels, but these have not yet reached the practical stage.

\subsection{Motor biofuel classified by the development stage}

Motor biofuels were commonly divided into first-generation, second-generation and third-generation biofuel depending on the

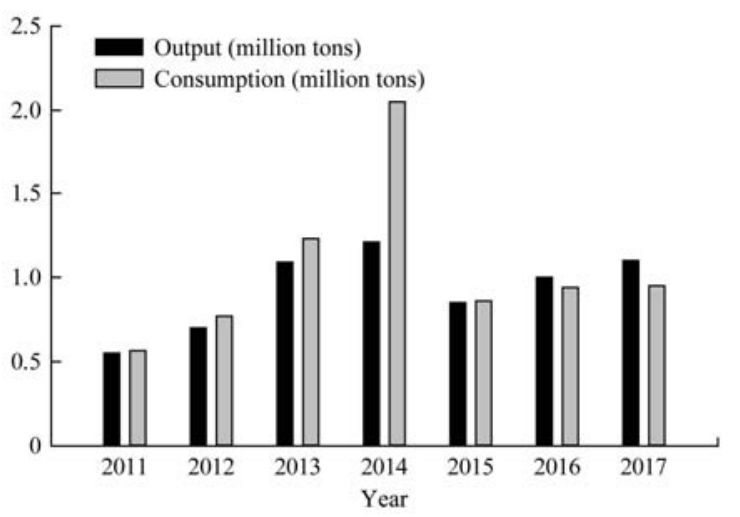

Source: Research and development prospects status and market forecast analysis of biodiesel in China (2018), China industry research network

Figure 2 Annual output and consumption of biodiesel in China from 2011 to 2017

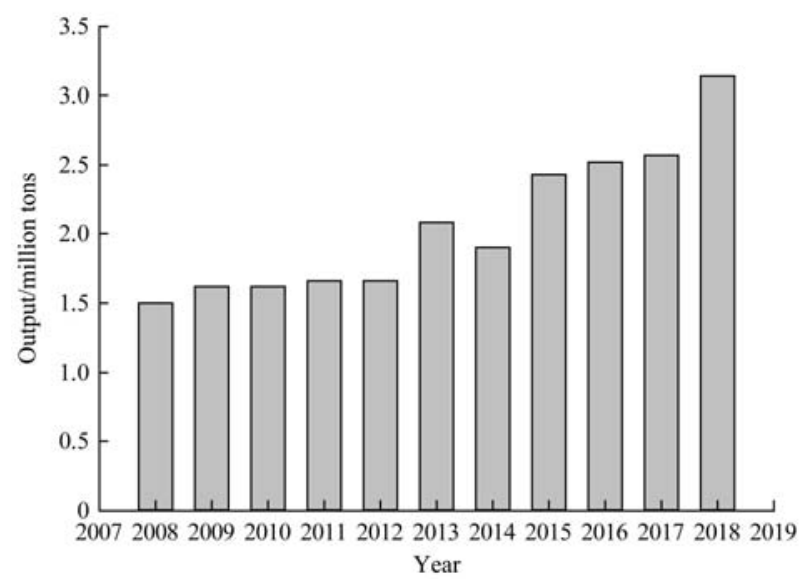

Source: Renewable fuels association analysis of public and private data sources.

Figure 4 Bioethanol production of China from 2008 to 2018

maturity of the technologies. Bioethanol, as a representative of the first-generation biofuel, has been developed to maturity and achieved commercialization. However, the first-generation motor biofuel faced with the problem of fighting for food with people, fighting for land with grain, and difficulties in large-scale development ${ }^{[3,41]}$.

The raw materials of the second-generation motor biofuel were non-grain crop and waste after pretreatment, enzymatic degradation, scarification, and the fermentation process. The main representatives of the second-generation motor biofuels were biosynthesis diesel, non-grain crop bioethanol, Fischer-Tropsch synthesis biofuel, cellulosic bioethanol, dimethyl ether, butanol, and methanol. The second-generation motor biofuel was the principal direction for motor biofuel nowadays. However, the second-generation motor biofuel technologies faced some issues in the large-scale application ${ }^{[3,41]}$.

The third-generation motor biofuel regards algae as the raw material and extracts the accumulated oil during the process of growth. Algae has many varieties, a wide distribution, strong adaptability, short growth period, high oil content, and do not compete for food with people, or fight for land with grain, which has led the third-generation motor biofuel to attract much more attention. The third-generation motor biofuels have not been commercialized and were still in the laboratory research stage. The main technical issues that the third-generation motor biofuel face was as follows: species selection from thousands of algae, quantity control during the 
process of algae culturing, algae harvesting, oil extraction technology, and the high cost of extraction (which costs about
$5.75 \$ / \mathrm{L}$ ). The motor biofuel conversion technology roadmap is shown in Figure $5^{[3,41]}$.

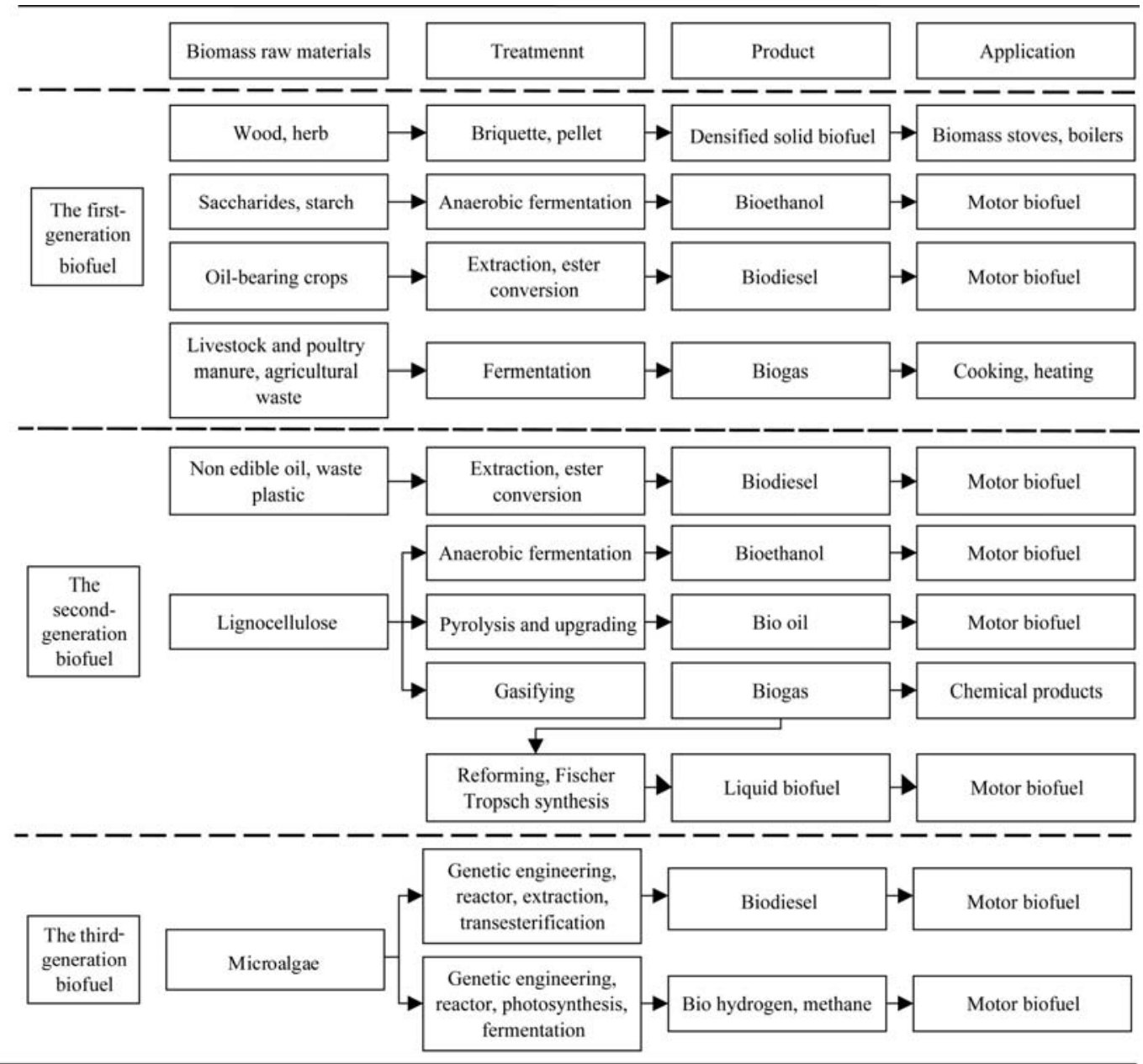

Figure 5 Roadmap for the conversion and utilization of moto biofuel

\section{Policies and measures taken globally to promote the development of motor biofuel}

Motor biofuel as one type of renewable and sustainable energy has been attracted wide interest all over the world, and various policies and measures have been taken with the intention to promote the development of motor biofuel.

In the USA, as the largest bioethanol production country, the raw material used for bioethanol production was corn. The USA was also the second-largest biodiesel producer in the world, mainly using soybeans as the unprocessed material. The consumption of renewable energy will reach 36 billion gallons until 2022 as stipulated in Energy Independence and Security Act of 2007, which accounts for $22 \%$ of the total vehicle fuel consumption ${ }^{[42]}$. The government provided corresponding subsidies in order to encourage using corn for bioethanol production as stipulated by New Energy Bill promulgated in 2007. The United States Federal Government and the States have introduced corresponding policies and measures to promote the development of motor biofuel including the reduction of fuel tax, providing appropriate subsidy for motor biofuel production unit and individual, tax breaks for users who purchase motor biofuel vehicle, and vehicles that belong to state governments must use a certain proportion of motor biofuel $^{[43,44]}$

The development and utilization of bioethanol in Brazil were the most characteristic in the world. Bioethanol Project was implemented in Brazil since 1975. Brazil was the second-largest bioethanol production country. Sugarcane was the main raw material used for bioethanol production in Brazil ${ }^{[45]}$. The Brazilian government required that fuel used for diesel engines must be blending with $2 \%$ biodiesel (volume ratio) ${ }^{[46-48]}$. The annual production capacity of bioethanol in Brazil was about 25.69 million $t$ (Date from Renewable Fuels Association of the USA).

The EU needed to import large quantities of diesel every year due to the shortage of diesel. Therefore, the EU has paid great attention to the development of biodiesel technology, and the EU was one of the earliest regions to promote biodiesel. The biodiesel output and consumption of the EU ranked first in the world. In order to decrease the reliance on energy importation, the EU had taken some measures to promote the development of biodiesel in the late 1980s and early 1990s, such as providing subsidy for the cultivation of energy crops and preferential treatment for bioenergy product ${ }^{[44]}$.

Since the 1990s, France has taken measures to encourage the development of biofuels such as reducing consumption tax and pollution tax for biofuel products ${ }^{[41,49]}$.

The main biofuel used in Germany is biodiesel. Measures had been taken by the German government to promote the development of motor biofuel was to reduce the mineral oil tax and environmental tax. Since 2002, biodiesel fuel production in Germany has become greater than in France. The biodiesel fuel 
production of Germany was ranked number one in 2008, followed by France and Italy ${ }^{[4,46]}$.

Sweden introduced $\mathrm{CO}$ emission tax and ultra-low sulfur diesel in the 1990s. The government of Sweden tried to reduce their dependence on fossil energy and looked forward to environmentally friendly products according to their energy characteristics $^{[44,50]}$.

The EU converted ethanol into ethyl tert butyl ether (as a component of blended gasoline $)^{[51]}$. The European Commission proposed that promoting the development of the second-generation motor biofuel and bio-hybrid technology in the European Strategic Energy Technology Plan, which was published in 2007. The main raw materials used for biodiesel production in the EU were rapeseed oil, soybean oil, palm oil, and recycling plant/animal oil. Member states of the EU should increase their proportion of biodiesel year by year and reach $20 \%$ in $2020^{[52]}$. The EU has taken measures to make the price of biodiesel lower than that of diesel by reducing fuel tax and commodity tax. In addition, the EU has encouraged the planting of non-edible oil crops and awarded the appropriate subsidy. Large scale automobile manufacturer was also cooperating to promote the development of biodiesel industry.

India published its National Biofuel Policy, which provided that $10 \%$ of bioethanol (volume ratio) should be added in the fuel for transport vehicles ${ }^{[53]}$.

In order to promote the development of producing bioethanol from cellulose, the Japanese government issued a New National Energy Strategy and the Strategy of Comprehensive Approach ${ }^{[54]}$.

South Korea has implemented $\mathrm{CO}_{2}$ emission trading since 2013 through the use of M-ETBE for $\mathrm{CO}_{2}$ emission right ${ }^{[55]}$.

The Australians used butter, palm oil, and recovered oil for biodiesel production. The price of raw material was relatively low, which can bring considerable economic benefit ${ }^{[56,57]}$.

Canadian decomposed cellulose from corn straw to surge treated by enzyme and then produced bioethanol through the fermentation process. In addition, the Philippines, Mexico, and other countries were also actively promoting the development of their own motor biofuel industry ${ }^{[58]}$.

In order to encourage the development of biofuel, the Chinese government has promulgated the Financial Management of Flexibility Subsidy for bioethanol and Notice on the Adjustment of Tax policy for Modified Bioethanol Production Enterprises ${ }^{[59]}$. China developed a national standard for biofuel in 2010, which was known as the Chinese National Standard (GB18351-2001, Ethanol Gasoline for Motor Vehicles) ${ }^{[60]}$. Unleaded gasoline was disabled and gasoline with $10 \%$ ethanol (volume ratio) was promoted in 27 provinces such as Heilongjiang, Jilin, Liaoning, Henan, Anhui, Hebei, Shandong, Jiangsu, and Hubei ${ }^{[61]}$. The National Development and Reform Commission pointed out that China had already achieved a production capacity of 10 million $t$ of ethanol-gasoline each year and ethanol-gasoline consumption accounted for $20 \%$ of the domestic gasoline consumption. China became the third-largest ethanol-gasoline production country ${ }^{[62]}$. In order to promote the development of biodiesel, the Chinese government released nationwide standards for biodiesel such as the Biodiesel Blend Stock (BD100) for Diesel Engine Fuels in 2007 and Biodiesel Fuel Blend (B5) in 2014 ${ }^{[63]}$. Biodiesel fuel used in China were a mixture of diesel and 5\%-20\% biodiesel. Another policy taken in China to promote the development of biodiesel was value-added tax rebate.

\section{Problems faced during the development of motor biofuel}

There are few problems faced with the development of motor biofuel, which affect the large-scale application of motor biofuels.

(1) It fights for food with humans and fights land with food. Data from the Food and Agriculture Organization of the United Nation have shown that the increasing rate of world grain output was lower than the grain demand growth rate. Therefore, world grain stocks have declined year by year. World grain stock was 405 million $t$ in 2008 , which can only maintain a cancellation fee for $57 \mathrm{~d}^{[64]}$. The reason was the growth in the global population, the waste of food, and another very important reason was that part of the grain used for biofuel production. Converting food to energy will affect food security, causing food prices to rise, famine, riot and conflict between regions and nations.

(2) Technology using grain to produce motor biofuel was not mature. There has been no breakthrough in key technologies for motor biofuel production. The development of motor biofuel still faced lots of problems such as the collection and transportation of biomass raw material, purification, transportation, and storage of biofuel production.

(3) The development of biofuel will affect the ecological environment, bringing irreversible change that will cause the over development and utilization of resources, and affect the sustainable development of the ecology and environment.

Smith concluded that $\mathrm{N}_{2} \mathrm{O}$ emissions during the planting process of rapeseed and corn were three times greater than that of estimated. This $\mathrm{N}_{2} \mathrm{O}$ was mainly caused by the utilization of nitrogen fertilizer. The atmosphere destroying the capacity of $\mathrm{N}_{2} \mathrm{O}$ was about 300 times greater than that of $\mathrm{CO}_{2}{ }^{[65]}$. The destruction of the atmosphere caused by burning corn bioethanol was 1.5 times greater than that caused by gasoline and the destruction of the atmosphere caused by burning rapeseed biodiesel was 1.7 times greater than that caused by diese ${ }^{[65]}$.

The development of motor biofuel had increased greenhouse gas emissions in other ways. The production of the biofuel raw materials occupied a large amount of land, which will destroy the Amazon rainforest, the Atlantic tropical rainforest, grasslands, and woodland. The rapidly expanding palm tree planting areas in Southeast Asia have led to tropical rainforest destruction. Palm tree planting areas in Malaysia have increased from 64.2 thousand $\mathrm{hm}^{2}$ in 1975 to $400 \mathrm{hm}^{2}$. Eighty percent of the cut rainforest land was used to grow palm trees ${ }^{[66]}$. The reduction of tropical rain forest not only destroyed the biodiversity but also accelerated the pace of global warming and brought disastrous consequences. In Brazil, using sugarcane as the raw material to produce bioethanol has resulted in the sugarcane planting area being increased year by year, and a large number of grasslands and forest land have been destroyed to plant sugarcane.

Destroying forest, wetland, grassland and other natural ecological regions to plant motor biofuel raw materials has led to the change of the carbon content in soil, which was sufficient to offset the reduction of greenhouse gas emissions by burning biofuel. Scientists discovered that, if all the factors of raw material cultivation and production were fully considered, $\mathrm{CO} 2$ emissions from biofuel burning was 2-8 times higher than that of fossil fuel burning. It cost 319 years to repay the debt of $\mathrm{CO}_{2}$ if the Amazon rainforest is deforested to plant soybean or sugarcane for motor biofuel production ${ }^{[67]}$. Furthermore, the motor biofuel production process required a large amount of water, so will place greater 
pressure on the shortage of water resources.

According to the above views, much more researches should be done with motor biofuel, especially the Life Cycle Assessment of motor biofuel.

(4) The cost of motor biofuel production was high, and the cost of the input-output ratio was not ideal. Motor biofuel cannot completely replace fossil fuel due to the high cost and disadvantage in quality and technology. Additionally, the scale and market still need to be strengthened. David and $\mathrm{Tad}^{[68]}$ found that the energy input and output ratio of soybean biodiesel fuel was 1.27: 1, and the energy input and output ratio of sunflower biodiesel fuel was 2.18:1. The same situation was also found in bioethanol production using corn as the raw material.

(5) Motor biofuel production capacity was restricted. Traditional motor biofuel production was difficult in having a magnitude breakthrough due to the raw material sources. Bioethanol production in the USA was about 57 billion L/a, even if fully liberalized, the bioethanol production capacity of the USA can meet only $6 \%$ of the transportation fuel demand. However, it consumed 139 million $t$ of corn, almost half of the total corn production of the USA in $2008^{[69]}$. The USA government planned the annual output of bioethanol reached 132.5 billion L until 2017. If only using corn as the raw material, it needs 318 million $\mathrm{t}^{[70]}$. This meant that in order to meet the bioethanol demand for corn, the annual yield of corn must continue to increase. In order to consume the stale grain that could not be utilized as a food staple, the Chinese government launched several bioethanol projects. However, the stale grain could not meet the demand for bioethanol production as the scale of the bioethanol production enterprise increased. Bioethanol production enterprises started to use new grain for bioethanol production.

(6) The acceptability of motor biofuel was not high despite the fact that motor biofuels are promoted globally. Motor biofuel production enterprises, employees, and researchers should seriously consider the issue of whether the motor biofuel industry will move into fluctuation development after rapid development.

\section{Recommendations for motor biofuel development in China}

The motor biofuel industry was a huge industrial system with a broad market and prospects for its development. In order to promote the development of biofuel, a long-term development plan for renewable energy pointed out that biofuel will replace 10 million $t$ of fossil fuels by 2020. The key factors that influence motor biofuel achieving large-scale development were ways to deal with problems introduced by production, market, and sales, especially the development of technical standards. The government should take steps to encourage investment, make, price, write tax policies, and provide sale channels for motor biofuel. Large energy companies should play a lead role in promoting the development of motor biofuel.

\subsection{Survey and evaluation of land resources}

The basis of motor biofuel was adequate biomass resources. The government should survey and assess the land resources that are appropriate for planting sweet sorghum, cassava, jatropha, and other energy crops, then make plans for energy crops and oil plants. 6.2 Construction of non-grain motor biofuels demonstration projects

On the basis of analyzing the resources situation in China, it was necessary to construct bioethanol production demonstration projects using corn as the raw material in different provinces including Shandong, Heilongjiang, Inner Mongolia, and Xinjiang, and construct Jatropha oil biodiesel fuel production demonstration projects in Sichuan, Guizhou, and Yunnan Provinces in China.

\subsection{Completing the acquisition, circulation and standard system}

PetroChina and Sinopec should establish non-grain biofuel acquisition, distribution, and sales networks. Non-grain biofuels that meet the quality standard can purchase by the network. Technical indicators and production lines for motor biofuel production are different due to the difference of raw material, therefore standards suited for these were faced with some problems, such as imperfect technical index system, not having a uniform standard for the process of design, and production control requirements.

\subsection{Enhancing the research on motor biofuel production technology}

There was still a considerable gap between the production system and the scale of energy crop planting, even though China became the third-largest bioethanol production country following the USA and Brazil. The government should take measures to support research on motor biofuel production technology and the industrialization of motor biofuel, such as the selection of biological resources, biofuel processing technology, and research on technology using cellulose to produce liquid fuel ${ }^{[66,71,72]}$. The Ministry of Agriculture and Rural Affairs of the People's Republic of China and the State Forestry Administration of the People's Republic of China should encourage the breeding and promotion of energy crops and oil plants.

\subsection{Improving the tax policy}

It can be summarized that tax policies were helpful in promoting the development of the motor biofuel industry from the experience of the countries outside of China. Therefore, the following suggestions can be obtained:

(1) Reduce and exempt different proportions of tax for biofuel production according to the proportion of biofuel fuel used.

(2) Reduce and exempt motor biofuel production enterprises and vehicle production enterprises using motor biofuel.

(3) Provide appropriate subsidies for farmers who plant oil crops and energy crops.

(4) Improve the motor biofuel service industry and increase the investment in infrastructure.

\subsection{Improving the market environment}

The development of the motor biofuel industry requires a quality market environment. The government should take measures to initiate, encourage, and support enterprises to actively participate in the production of motor biofuels and to form a stable, open and fair market environment.

\section{Acknowledgements}

This study was financially supported by the joint projects of the Doctoral Research Fund of Shandong Jianzhu University (Grant No. X18042Z), the National Natural Science Foundation of China (Grant No. 51806242) and the Open Research Fund Program of Key Laboratory of Cleaner Production and Integrated Resource Utilization of China National Light Industry (Grant No. CP-2020-YB11).

\section{[References]}

[1] Prakash S, Prabhahar M, Sendilvelan S, Venkatesh R, Singh S, Bhaskar K Experimental studies on the performance and emission characteristics of an automobile engine fueled with fish oil methyl ester to reduce 
environmental pollution. Energy Procedia, 2019; 160: 412-419.

[2] Kathirvelu B, Subramanian S, Govindan N, Santhanam S. Emission characteristics of biodiesel obtained from jatropha seeds and fish wastes in a diesel engine. Sustainable Environment Research, 2017; 27(6): 283-290.

[3] Zhang J R. Research on evaluation and decision of research and development towards the motor biofuel technology. Master dissertation. Wuhan: Wuhan University of Technology, 2014; 88p. (in Chinese)

[4] Luo Y T, Xu Y J, Tang X H, Li Y C. Prospect of the development of alternative fuels in China. International Petroleum Economics, 2013; 21(10): 77-86. (in Chinese)

[5] Şanli B G, Uludamar E, Özcanli M. Evaluation of energetic-exergetic and sustainability parameters of biodiesel fuels produced from palm oil and opium poppy oil as alternative fuels in diesel engines. Fuel, 2019; 285: 116116. doi: 10.1016/j.fuel.2019.116116.

[6] Mohd N C W, Noor M M, Mamat R. Biodiesel as alternative fuel for marine diesel engine applications: A review. Renewable \& Sustainable Energy Reviews, 2018; 94: 127-142.

[7] Tang X H, Li X F, Luo Y T, Kong J Y. Development and prospects of alternative fuels for vehicles in China. Petroleum Planning and Engineering, 2012; 23: 15-46. (in Chinese)

[8] Rostek E, Biernat K. Analysis of quality parameters of selection motor biofuels, taking into account the current requirement of the worldwide fuel charter. Journal of Kones, 2015; 19(2): 449-458.

[9] Geng P, Cao E M, Tan Q M, Wei L J. Effects of alternative fuels on the combustion characteristics and emission products from diesel engines: A review. Renewable \& Sustainable Energy Reviews, 2017; 71: 523-534.

[10] Datta A, Mandal B K. Numerical investigation of the performance and emission parameters of a diesel engine fuelled with diesel-biodiesel-methanol blends. Journal of Mechanical Science and Technology, 2016; 30(4): 1923-1929.

[11] Mofijur M, Rasul M G, Hyde J, Azad A K, Mamat R, Bhuiya M M K. Role of biofuel and their binary (diesel-biodiesel) and ternary (ethanol-biodiesel-diesel) blends on internal combustion engines emission reduction. Renewable and Sustainable Energy Reviews, 2016; 53: $265-278$.

[12] Lebedevas S, Vaicekauskas A, Lebedeva G, Janulis P, Kazancevet K. Use of waste fats of animal and vegetable origin for the production of biodiesel fuel: quality, motor properties, and emissions of harmful components. Energy Fuels, 2006; 20(5): 2274-2280.

[13] Martin N, Lombard M, Jensen K R, Kelleya P, Pratta T, Traviss N. Effect of biodiesel fuel on "real-world", nonroad heavy duty diesel engine particulate matter emissions, composition and cytotoxicity. Science of the Total Environment, 2017; 586: 409-418.

[14] Ma G Y, Ni J H. Development status and route of China's bio fuel industry. Manager Journal, 2016; 2: 44-45.

[15] Wu X, Zhang S J, Guo X, Yang Z J, Liu J Q, He L Q, et al. Assessment of ethanol blended fuels for gasoline vehicles in China: Fuel economy, regulated gaseous pollutants and particulate matter, Environmental Pollution, 2019; 253: 731-740.

[16] Erdiwansyah, Mamat R, Sani M S M, Sudhakar K, Kadarohman A, Sardjono R E. An overview of higher alcohol and biodiesel as alternative fuels in engines. Energy Reports, 2019; 5: 467-479.

[17] Yusri I M, Majeed A P P A, Mamat R, Ghaazal M F, Awad O I, Azmi W H. A review on the application of response surface method and artificial neural network in engine performance and exhaust emissions characteristics in alternative fuel. Renewable \& Sustainable Energy Reviews, 2018; 90: 665-686.

[18] Fayad M A, Tsolakis A, Martos F J. Influence of alternative fuels on combustion and characteristics of particulate matter morphology in a compression ignition diesel engine. Renewable Energy, 2020; 149: 262-969.

[19] Zhao Y Q. Development status and prospect of alternative fuels for vehicles. China Energy, 2009; 31(4): 33-36. (in Chinese)

[20] Kluschke P, Nugroho R, Gnann T, Plötz P, Wietschel M, Reuter-Oppermann M. Optimal development of alternative fuel station networks considering node capacity restrictions. Transportation Research Part D: Transport and Environment, 2020; 78: 102189. doi: 10.1016/j.trd.2019.11.018.

[21] Hosseinnia H, Modarresi J, Nazarpoura D. Optimal eco-emission scheduling of distribution network operator and distributed generator owner under employing demand response program. Fuel, 2020; 191: 265: 116553. doi: 10.1016/j.energy.2019.116553.

[22] Li G, Bai X, Huo S H, Huang Z G. Fast pyrolysis of LERDADEs for renewable biofuels. IET Renewable Power Generation, 2020; 14(6): 959-967.

[23] Khan H M, Iqbal T, Ali C H, Javaid A, Cheema I I. Sustainable biodiesel production from waste cooking oil utilizing waste ostrich (Struthio camelus) bones derived heterogeneous catalyst. Fuel, 2020; 177: 118091. doi: 10.1016/j.fuel.2020.118091

[24] Chozhavendhan S, Singh M V P, Fransila B, Kumar B, Devi K. A review on influencing parameters of biodiesel production and purification processes. Current Research in Green and Sustainable Chemistry, 2020; 1-2: $1-6$.

[25] Sanchez N, Ruiz R, Hacker V, Cobo M. Impact of bioethanol impurities on steam reforming for hydrogen production: A review. International Journal of Hydrogen Energy, 2020; 45(21): 11923-11942.

[26] Sun L J. Alcohol fuel industry prospect. Chemical Industry, 2011; 29(1): 8-12. (in Chinese)

[27] Dharma S, Ong H C, Masjuki H H, Sebayang A H, Silitonga A S. An overview of engine durability and compatibility using biodiesel-bioethanol-diesel blends in compression-ignition engines. Energy Conversion and Management, 2016; 128: 66-81.

[28] Li Z Y, Li D J, Huang G X, Wei H R. Insights on current development of fuel ethanol. Chemical Industry and Engineering Progress, 2013; 7 : 1457-1467. (in Chinese)

[29] Ko J K, Lee S M. Advances in cellulosic conversion to fuels: Engineering yeasts for cellulosic bioethanol and biodiesel production. Current Opinion in Biotechnology, 2018; 50: 72-80.

[30] Nagarajan S, Skillen N C, Irvine J T S, Lawton L A, Robertson P K J. Cellulose II as bioethanol feedstock and its advantages over native cellulose. Renewable \& Sustainable Energy Reviews, 2017; 77: 182-192.

[31] Ndukwe J K, Aliyu G O, Onwosi C O, Chukwu K O, Ezugworie F N. Mechanisms of weak acid-induced stress tolerance in yeasts: Prospects for improved bioethanol production from lignocellulosic biomass. Process Biochemistry, 2020; 90: 118-130

[32] Aditiya H B, Mahlia T M I, Chong W T, Nur H, Sebayang A H. Second generation bioethanol production: A critical review. Renewable and Sustainable Energy Reviews, 2016; 66: 631-653.

[33] Yee K F, Mohamed A R, Tan S H. A review on the evolution of ethyl tert-butyl ether (ETBE) and its future prospects. Renewable \& Sustainable Energy Reviews, 2013; 22: 604-620.

[34] Levchuk I, Bhatnagar A, Sillanpaeae M. Overview of technologies for removal of methyl tert-butyl ether (MTBE) from water. Science of the Total Environment, 2014; 476-477: 415-433.

[35] Mutsengerere S, Chihobo C H, Musademba D, Nhap I. A review of operating parameters affecting bio-oil yield in microwave pyrolysis of lignocellulosic biomass. Renewable \& Sustainable Energy Reviews, 2019; 104: 328-336.

[36] Li G, Ji F, Bai X, Zhou Y G, Dong R J, Huang Z G. Comparative study on thermal cracking characteristics and bio-oil production from different microalgae using Py-GC/MS. Inter J Agric \& Biol Eng, 2019; 12(1): 208-213.

[37] Mei D Q, Guo D M, Wang C, Dai P F, Du J Y, Wang J F. Evaluation of esterified pyrolysis bio-oil as a diesel alternative. Journal of the Energy Institute, 2020; 93(4): 1382-1389.

[38] Sebola M, Tesfagiorgis H, Muzenda E. Effect of particle size on anaerobic digestion of different feedstocks. South African Journal of Chemical Engineering, 2015; 20(3): 11-26.

[39] Brown D, Shi J, Li Y. Comparison of solid-state to liquid anaerobic digestion of lignocellulosic feedstocks for biogas production. Bioresource Technology, 2012; 124(11): 379-386.

[40] Baniamerian H, Isfahani P G, Tsapekos P, Alvarado-Morales M, Shahrokhi M, Vossough M, et al. Application of nano-structured materials in anaerobic digestion: Current status and perspectives. Chemosphere, 2019; 229: 188-199.

[41] Zhang J X. Production and upgrading of bio-oil in sub and supercritical fluids. PhD dissertation. Hangzhou: Zhejiang University, 2013; 154p. (in Chinese)

[42] Dinneen B, Chuck W, Neill M, Walter W, Randall D, Chris S Accelerating industry innovation. 2012 Ethanol industry outlook. Washington, DC: Renewable Fuels Association, 2012; pp.16-19.

[43] Richard H, Partrick L, Carl W. International Energy Agency bioenergy task 40 sustainable international bioenergy trade securing supply and demand country report 2014-United States. US: International Energy Agency, 2015.

[44] Tian D L, Zhang H, Gao H Y. Analysis of the policy and measures of 
promoting biofuel in foreign countries. Bus Technology and Research, 2009; 32(2): 58-61. (in Chinese)

[45] Galbe M, Zacchi G. A review of the production of ethanol from softwood. Applied Microbiology and Biotechnology, 2002; 59: 618-628.

[46] Zhang M, Cao Y Z, Li Z B. On the advance and prospect of research of fuel alcohol. Journal of Hunan University (Natural) Sciences, 2007; 4(28): 89-93. (in Chinese)

[47] Pao H T, Fu H C. Renewable energy, non-renewable energy and economic growth in Brazil. Renewable \& Sustainable Energy Reviews, 2013; 25(5): 381-392.

[48] Mabee W E, Saddler J N. Bioethanol from lignocellulosic: Status and perspectives in Canada. Bioresource Technology, 2010; 101(101): 4806-4813.

[49] Doumax-Tagliavini V, Sarasa C. Looking towards policies supporting biofuels and technological change: Evidence from France. Renewable \& Sustainable Energy Reviews, 2018; 94: 430-439.

[50] Bryngemark E. Second generation biofuels and the competition for forest raw materials: A partial equilibrium analysis of Sweden. Forest Policy and Economics, 2019; 109: 102022. doi: 10.1016/j.forpol.2019.102022.

[51] Londo M, Lensink S, Wakker A, Andre W, Gunther F, Sylvia P. The REFUEL EU road map for biofuels in transport: application of the project's tools to some short-term policy issues. Biomass \& Bioenergy, 2010; 34(2): 244-250.

[52] Bowyer C. Anticipated indirect land use change associated with expanded use of biofuels and bioliquids in the EU: An analysis of the national renewable energy action plans. 2010, www.ieep.eu. Accessed on [2018-09-10]

[53] Saravanan A P, Mathimani T, Deviram G, Rajendran K, Pugazhendhi A. Biofuel policy in India: A review of policy barriers in sustainable marketing of biofuel. Journal of Cleaner Production, 2018; 193: 734-747.

[54] Kim B, Sargolzehi M M, Lee B, Min B R. Effect of cultivars and planting dates on bioenergy feedstock characteristics of switchgrass (Panicum virgatum) in South Korea. Adsa-Asas-Csas Joint Meeting, 2014; 92: 1118 .

[55] Sakai S. Bioenergy policies in Japan. Environmental Information Science, 2009; 38(3): 15-21

[56] Azad A K, Rasul M G, Khan M M K, Sharma S C, Hazrat M A. Prospect of biofuels as an alternative transport fuel in Australia. Renewable \& Sustainable Energy Reviews, 2015; 43: 331-351.

[57] Hathurusingha S, Ashwath N, Midmore D. Periodic variation in kernel oil content and fatty acid profiles of Calophyllum innophyllm L: A potential biodiesel feedstock in Australia. Biomass \& Bioenergy, 2011; 35(8): 3448-3452.

[58] Doug B. Canada biomass-bioenergy report. US: International Energy Agency, 2006; 20p.

[59] Hao N, Liu Z W, Zhao F Q, Ren J Z, Chang S Y, Rong K, et al. Biofuel for vehicle use in China: Current status, future potential and policy implications. Renewable and Sustainable Energy Reviews, 2018; 82: 645-653.

[60] Zhang Y G, Liu S T, Yang G X. Research on the feasibility of ethanol gasoline for motor vehicles. Petroleum Refinery Engineering, 2002; 32(9): 43-45. (in Chinese)

[61] Li M H, Zhang W D, Hayes D, Arthur R, Yang Y T, Wang X D. China's new nationwide E10 ethanol mandate and its global implications. Agricultural Policy Review, 2017. http://www2.econ.iastate.edu/faculty/zhang/publications/outreach-articles/ Li_Zhang_Hayes_APR_2017_China_E10_Mandate.pdf. Accessed on [2020-06-21]

[62] Wu X, Zhang S J, Cao X, Yang Z J, Liu J Q, He L Q, et al. Assessment of ethanol blended fuels for gasoline vehicles in China: Fuel economy, regulated gaseous pollutants and particulate matter. Environmental Pollution, 2019; 253: 731-740.

[63] Duan M W. Study for biodiesel on detection technology and evaluation system. Master dissertation. Haikou: Hainan University, 2012; 86p. (in Chinese)

[64] Wu J. Research on the grain reserve system optimization based on food security. PhD dissertation. Wuhan: Huazhong Agricultural University, 2012; 140p. (in Chinese)

[65] Smith K A, Mosier A R, Crutzen P J, Wilfried W. The role of $\mathrm{N}_{2} \mathrm{O}$ derived from crop-based biofuels, and from agriculture in general, in Earth's climate. Philosophical Transactions of the Royal Society B: Biological Sciences, 2012; 367(1593): 1169-1174.

[66] Mohammed M A A, Salmiaton A, Azlina W A K G W, Amrana M S M, Fakhru'l-Razia A, Taufiq-Yap Y H. Hydrogen rich gas from oil palm biomass as a potential source of renewable energy in Malaysia. Renewable \& Sustainable Energy Reviews, 2011; 15(2): 1258-1270.

[67] Christos Z, Georgios C, Gregory S. Atmospheric $\mathrm{N}_{2} \mathrm{O}$ releases from biofuel production systems: A major factor against " $\mathrm{CO}_{2}$ emission savings": A global view twenty years of ozone decline. Springer Netherlands, 2009; pp.67-70.

[68] David P, Tad W P. Ethanol production using corn, switchgrass, and wood; biodiesel production using soybean and sunflower. Natural Resources Research, 2005; 14(1): 65-76.

[69] Qian B Z. United States EISA to determine the renewable fuel standards. Petroleum Refinery Engineering, 2008; 38(7): 62.

[70] Vadas P A, Barnett K H, Undersander D J. Economics and energy of ethanol production from alfalfa, corn, and switchgrass in the Upper Midwest, USA. Bioenergy Research, 2008; 1(1): 44-55.

[71] Li G, Lu Z T, Zhang J, Li H, Zhou Y G, Zayan A M I, et al. Life cycle assessment of biofuel production from microalgae cultivation in anaerobic digested wastewater. Int J Agric \& Biol Eng, 2020; 13(1): 241-246.

[72] Li G, Bai X, Li H, Lu Z T, Zhou Y G, Wang Y K, et al. Nutrients removal and biomass production from anaerobic digested effluent by microalgae: A review. Int J Agric \& Biol Eng, 2019; 12(5): 8-13. 